\title{
TANULÁSBAN AKADÁLYOZOTT GYERMEKEK KOGNITÍV FEJLESZTÉSÉNEK LEHETŐSÉGEI
}

Szerzők:

Orbán Réka

Babes Bolyai Tudományegyetem

(Románia)

Szerző e-mail címe:

reka.orban@ubbcluj.ro

\section{Lektorok:}

János Réka

Babes Bolyai Tudományegyetem

(Románia)

Kiss Szidónia

Babes Bolyai Tudományegyetem

(Románia)

Mező Ferenc

Debreceni Egyetem

Mezö Katalin

Debreceni Egyetem

Orbán Réka (2015): Tanulásban akadályozott gyermekek kognitív fejlesztésének lehetőségei. Különleges Bánásmód, I. évf. 2015/2. szám, 81-86. DOI 10.18458/KB.2015.2.81

\begin{abstract}
Absztrakt
Jelen tanulmány a Sindelar-Zsoldos program alkalmazását mutatja be egy tanulásban akadályozott elemi osztályos gyermek esettanulmányán keresztül. Az elméleti rész a tanulásban akadályozott tanulók kognitív struktúrájára fókuszál. A módszertani rész azt fejti ki, hogy ha a kognitív struktúra harmonikus, akkor egy tanulásban akadályozott gyermek is sikeres lehet az iskolában és a teljes inklúzió lehetségessé válik.
\end{abstract}

Kulcsszavak: kognitív fejlesztés, kognitív képességek, Sindelar-Zsoldos program

Diszciplina: gyógypedagógia

\begin{abstract}
POSSIBILITIES OF COGNITIVE DEVELOPMENT OF CHILDREN WITH LEARNING DIFFICULTIES

This study presents the Sindelar-Zsoldos program through a case-study of an elementary school boy with learning difficulties. The theoretical part is focused on the cognitive structure of the learning of disabled students. The methodological part emphasizes that if the cognitive architecture is harmonized, then even a child with learning difficulties can be successful in the school and full inclusion is possible.
\end{abstract}

Keywords: cognitive development, cognitive skills, Sindelar-Zsoldos program

Disciplines: special education 


\section{Az értelmi akadályozottság fogalma és kognitív jellemzői}

A tanulásra való képesség az emberi létezés meghatározója és minőségének, fejlettségének mutatója. A tanulási folyamat szorosan összefügg az értelmi szint fejlődésével, de nem azonos vele, bizonyos esetekben színvonala magasabb lehet, mint az értelmi teljesítmény (Mesterházi, 1995).

A tanulásban akadályozottakra jellemző a kognitív müködés generalizált korlátozottsága, illetve számos képességük hiányzik vagy számottevően gyenge. A kognitív, nyelvi, motoros, pszicho-szociális képességek zavara erőteljesen befolyásolja mindennapi életüket (Westendorp és tsai, 2011).

Sarkady Kamilla és Zsoldos Márta (1992/93) vizsgálatai alapján elkülöníthetőnek tartja a tanulásban akadályozottak azon populációját, akik specifikus tanulási zavarokkal is küzdenek.

Tanulási zavarnak tekintik azt az - intelligenciaszint alapján elvárhatónál lényegesen alacsonyabb tanulási teljesítményt, amely neurológiai deficit vagy funkciózavar talaján jön létre, sajátos kognitív pszichológiai tüneteggyüttessel. A tanulási zavar társuló tünetként megjelenhet enyhe értelmi fogyatékosságnál, érzékszervi sérülésnél és beszédhibáknál. Ezekben az esetekben is (specifikus) tanulási zavarról beszélünk.

A legutolsó meghatározás a DSM-V (2013) valamennyire eltér az előzőektől: A személy hatékony és pontos észlelését és információ-feldolgozását zavaró sajátos nehézségeket nevezzük specifikus tanulási zavarnak. Ennek az idegrendszeri fejlődési zavarnak a tünetei az első iskolai években jelennek meg. Jellemző az olvasás, írás és/vagy matematikai képességek kialakulásának tartós zavara. A teljesítmény az érintett területen jelentősen elmarad a korosztályától elvárttól, vagy az elfogadható teljesítmény elérése nagy erőfeszítést igényel. Tanulási zavar elöfordulhat tehetséges személyeknél is, ilyenkor a tünetei csak akkor jelentkeznek, ha a felmérési eljárások vagy a tanulási követelmények olyan akadályt jelentenek, melyeket nem tud természetes intelligenciájával és kompenzációs stratégiákkal legyőzni. A specifikus tanulási zavarok egész életen át problémát jelentenek azokban a tevékenységekben, amelyekben ezekre a képességekre kell támaszkodnia, beleértve a munkahelyi teljesítményt is.

Piaget (in Demetriou, Shayer és Efklides, 1994) megismerésröl alkotott kognitív konstruktivista elmélete nagyban hozzájárult az információfeldolgozással kapcsolatos elméletek fejlődéséhez, melyek a kogníciót „folyamat-egésznek” tekintik, és amelyek körülhatárolt részei a részképességek: észlelés, figyelem, emlékezet, intermodalitás, szerialitás, téri orientáció.

Brigitte Sindelar (Sedlak és Sindelar, 2000) a kognitív képességek egy hierarchikusan szerveződő struktúrában helyezhetők el és a sikeres tanuláshoz ezek megfelelő müködése és együttmüködése kulcsfontosságú, a problémás gyermekek képességprofilja diszharmonikus. A részképességek elemi bázisfunkciók, melyek müködése és összerendeződése előfeltétele a komplexebb mentális müveleteknek, problémamegoldásnak, intelligenciának, az írás-, olvasás-, és számolási készségek kialakulásának (Affolter, 1972, Sindelar, 1994, Zsoldos, 1999).

A szenzomotoros rendszer differenciált fejlesztését célozza, és nagy hangsúlyt fektet a megelőzésre. Programját Affolter (1972) háromdimenziós észlelésfejlődési modelljére alapozva dolgozta ki. A vizuális, auditív és taktilo-kinesztéziás észleletek három fö kognitív területen, az emlékezeten, észlelésen és figyelmen keresztül, valamint három fejlödési szinten, modalitás-specifikus, intermodális és szeriális felfogáson át vezetnek azokhoz a magasabb rendü képességekhez, amelyek lehetővé teszik többek között az írás, olvasás és számolás elsajátítását is. A rácsszerkezet bármely pontján keletkező deficit gátja lehet az iskolában szükséges képességek kialakulásának. Sindelarnak a részképesség-kiesés vagy -gyengeség területének azonosítására kidolgozott vizsgálati módszerei és a korrekciót szolgáló gyakorlatok ezen gyenge pontok feltárására, illetve megerősítésére szolgálnak. 
Minden alulteljesítő diák jól tanítható. A leghatásosabb, ha minden gyereket egyéni sajátosságai, szükségletei szerint oktatunk, ezzel egyenlő esélyt biztosítunk számukra. A jó tanítás érdekes, tanulásra motiváló órák tartását jelenti. Ehhez szükséges, hogy a tanár megértse a tanulók egyéni szükségleteit, és ezeknek megfelelő oktatási programot dolgozzon ki.

A kognitív architektúra alappillére az észlelés (Kiss, Zsoldos, 2008). Engel-Yeger, HardalNasser, és Gal (2011) kutatása kimutatta, hogy az értelmileg akadályozottak szenzoros feldolgozási képességei atipikusak. Figyelmük önkéntelen, spontán, kevésbé tartós, könnyen elterelhető, valamint hullámzó és szétszórt. Hiányzik a figyelem megosztására való képesség (Szabó, 2006). Neuropszichológiai kutatások azt mutatják, hogy a figyelemzavarok jelentős tényezője a kognitív fejlődési rendellenességeknek, ami hátráltatja a tanulásban, az észlelésben és a motoros funkciókban az értelmileg akadályozott gyerekeket (DjuricZdravkovic, Japundza-Milisavljevic és Macesic-Petrovic, 2010).

Térben bizonytalanul tájékozódnak, a téri relációkat bizonytalanul ismerik fel és határozzák meg. Az egyszerübb téri helyzeteket, mint például a föl, le, elöre, hátra, stb. gesztusokkal kísért utasításokkal viszonylag gyorsan megértik, megtanulják, és végre is hajtják, azonban önállóan reprodukálni majd csak jóval később tudják. Az értelmileg akadályozott személyek körében a térbeli memória kapacitása csökkent (Alevriadou, 2010).

A továbbiakban a Sindelar-Zsoldos program alkalmazhatóságát mutatom be tanulásban akadályozott és specifikus tanulási zavaros gyermekre egy esettanulmány formájában.

\section{Az eset ismertetése}

Tíz éves, harmadik osztályos fiú. A szakértői bizottság véleményezése alapján tanulásban akadályozott, teljesítménye hullámzó és bizonyos feladatokban az elvártnál is sokkal gyengébben teljesít. A szülő kérte a felmérést, mivel a rendszeres foglalkozások ellenére sem javul az iskolai teljesítménye. A gyermek nagyon jó magaviseletü, könnyen kezelhetö, igyekvő, bármilyen feladatot szívesen elvégez. Szemüveges.

A gyermek legfontosabb anamnesztikus adatai: Problémamentes terhesség után, időre született (3600 g és $53 \mathrm{~cm}$ hossz). Nyugodt gyermek volt, könnyen alkalmazkodott, 3 hónapos korától átaludta az éjszakát. Járni 2 év és 1 hónaposan kezdett, a kúszás, mászás szakasza kimaradt a mozgásfejlődéséből. Beszédfejlődése nagyon lassan indult, most is halk és szükszavú, szókincse szegényes.

A szülö véleménye a gyermek jelenlegi fejlettségi szintjéről: Nagyon jó gyermek, segítőkész, sok mindent rá lehet bízni. Mosolygós, csendes, elfoglalja magát, sosincs vele különösebb baj. Kitartóan végzi a feladatait, és mégis gyengék a minősítései. Nem elégedett a fejlettségi szinttel, de az iskolától és a szakemberektől vár megoldást, hisz otthon minden rendben van.

Rövid pedagógiai vélemény: Nagyon visszahúzódó, szorongó, csendes gyermek. A tanulási kudarcok megviselik, emiatt gyakran szomorú. Feladatvégzéskor nagyon lassú, emiatt gyakran a szünetet is tanulásra szánja. Kimondottan müvészi hajlamú gyermek, szépen rajzol. A pedagógus nem érti hullámzó teljesítményét, például a verset délután felmondja, de másnap reggel már nem tudja.

Szegényes szókincse és szövegértési problémái miatt azonban az anyanyelv és matematika (föleg a szöveges feladatok) teljesítménye gyenge. Ha felolvassák közösen a feladatot és utána kérik a megoldást, jobban teljesít, mintha magában kellene elolvasnia azt.

Ezeken a területeken sokszor rosszabbul teljesít, mint egyik osztálytársa, akit értelmileg akadályozott kategóriába soroltak.

\section{A vizsgálóeljárás bemutatása}

A Sindelar vizsgálóeljárás részletes képet nyújt az iskoláskorú gyermekek kognitív architektúrájáról és alapvetően különbözik a pszichológiai tesztektől. A dinamikus, fejlesztési 
stratégia célja nem csupán az állapot meghatározása, hanem fejlődési, fejlesztési lehetőségek, irányvonalak kijelölése, az egyén tanulási, fejlődési potenciáljának megismerése. A hagyományos pszichometriával ellentétben, amely a kvantitatív mérésekre összpontosít, a fejlesztési diagnosztika a kvalitatív tényezőkre, a képességek minőségi elemzésére és értékelésére helyezi a hangsúlyt. A dinamikus felmérés a statikus tesztektől a céljaiban, folyamataiban, eszközeiben, értékelési helyzetében és az eredmények kiértékelésében különbözik (Falik és Feuerstein, 2005; Sindelar, 2010).

A tizenhét feladat kilenc kognitív képességet vizsgál, melyek az affolteri koncepcióban meghatározzák az iskolai teljesítményt. A bázisfunkciókon kívül kiterjed az intermodális és a szeriális képességek vizsgálatára is (Sindelar, 2010).

A részletes eredmények alapján választjuk ki a személyre szabott tréningprogramot.

\section{Az eredmények értelmezése}

A pedagógust igazolja, hogy nagyon lassan oldotta meg a feladatokat, hamar fáradt, így a vizsgálat során az elöírtnál sokkal több szünetre volt szüksége. Feltünően próbált a vizuális feladatokban olvasással, illetve szóbeli megfogalmazással kompenzálni (intermodális szintre emelve a feladatot).

A vizuális alak-háttér differenciálás feladatból kiderül, hogy vonalvezetése bizonytalan, a formákat megrajzolja, de a síkban nem tudja elhelyezni őket, forgatta a lapot a feladat elvégzése közben, sokszor fejjel lefelé tartotta, ezzel kompenzálva a síkbeli orientációs problémáit. Nagyon sok hibával dolgozott.

A vizuális szerialitást mérő feladatot nehezen értette meg, de a megértési nehézség leküzdése után szinte hibátlanul megoldotta a feladatot.

Az intermodális emlékezet feladatban kiderült, hogy kockázatvállalással próbálta növelni a helyes válaszok számát, de kevés hibát ejtett.

Az auditív alak-háttér differenciálás/tagolás feladatban azoknál a hangoknál rontott, melyeket írásban is felcserél.

Auditív emlékezet (versike megtanulása): a rövid részeket hibátlanul visszamondta elsőre, a teljes vers visszamondásánál a második sorban elakadt, kihagyta a végét és a negyedik sor első szavánál segítséget igényelt.

A téri orientációja bizonytalan, hét feladatból ötöt rontott.

A vizsgálat alatti magatartás elemzése: a vizsgálat alatti magatartása megfelelt annak, amit anyukája és tanítója is tapasztalt. Az új helyzetben kezdetben szorongó volt, de hamar oldódott. Nagyon készséges volt a kislány, jól lehetett vele dolgozni, és kiderült az is, hogy az iskolában feltünő lassúsága a kompenzálásnak köszönhető. A kompenzálásnak köszönhetően megnyúlt a végrehajtás ideje, de ugyanakkor ez is világossá tette, hogy a gyerek végre akarja hajtani a feladatot, csak nem képes rá.

A sikeresen megoldott feladatok növelték a motivációját. Ilyenkor a szünetet is kihagyta volna, csakhogy újabb sikerélményhez jusson. Reálisan értékelte a saját teljesítményét.

A fejlesztési program kijelölése és a fejlesztés megszervezése: a négy alapterület, melyen gondjai voltak: a vizuális alak-háttér megkülönböztetése, az auditív és vizuális differenciálás, valamint a téri orientáció - ennek megfelelően az Útmutató (2010) alapján a 142-es tréningprogramot alkalmazzuk. A tanító végzi a napi fejlesztést, melyet kiegészít az a meixneri alapelveken nyugvó diszlexia-terápia (föleg tévesztett betük: $c-c s, s z-z s, s-s z, z-z s$, és az ékezetes betűk) újratanítása és differenciálása. A tréningprogramhoz szükséges anyagokat biztosítom a tanító számára és konzultálok vele, bemutatom az újabb gyakorlatot, valamint a gyermekkel is találkozom hetente egyszer. 


\section{A fejlesztés eredményei}

A tízperces időkeret és a sikerélmény biztosítása jelentette az első eredményeket. Ha a felmérőkor azt hallotta, hogy tízperces feladatról van szó, akkor nagyon motiválttá vált és sikerorientálttá vált a magatartása, ez a fokozott figyelem pedig az érdemjegyben is tükröződött.

\section{Az elsö tréningfázis}

A vizuális alak-háttér 1+2-es füzet feladatlapjait könnyedén megoldotta, néha szükséges volt egyik-másik feladat megismétlése, mert hibázott a részletek kivitelezésében.

A téri orientáció füzet első feladatai, melyek a taktilis észlelést fejlesztik, szintén könnyüek voltak, a mozdulatutánzásos feladatok azonban már nehezebbeknek bizonyultak, a jobb-bal irányok differenciálása miatt. A robotjátékban végül sikerélménye volt, így azt többször is játszottuk jutalomként is.

Az auditív differenciálás esetében nehézséget a hasonló hangok differenciálása jelentette, amikor nem ismételhette meg a szavakat.

\section{A második tréningfázis}

A hosszú és rövid hangok auditív differenciálása elég könnyedén ment, viszont a történetek olvasása után hangsúlyt kapott a szókincsbővítés is.

A vizuális differenciálás feladatok ismerősek voltak, és viszonylag könnyen mentek. Az apró különbségeket mediálni kellett, de a másodszori vagy harmadszori kirakás már helyes volt.

A téri orientáció „építős” feladatai nagyon tetszettek neki, miután megértette, mit jelent minta alapján építeni, jól haladt. Elakadás a sziluett kép utáni építéskor következett be, de néhány próbálkozás után jól megoldotta.

\section{A harmadik tréningfázis}

A vizuális alak-háttér differenciálás feladatok során meg kellett tanulnia az ábécé-sorrendet, ezt külön mediálni kellett, és részletekben megtanítani, ahhoz, hogy használni tudja a feladatmegoldáshoz. A későbbiekben viszont a szótárhasználathoz is szükséges lesz. A végén pedig szüksége volt a szókincsbővítésre ahhoz, hogy az adott betüt tartalmazó szavakat megtalálja. Az auditív differenciálás feladatokban a tévesztett hangpárokat többször is gyakorolnunk kellett. A téri forgatás feladatokat nehezen értette meg, de végül sikeres volt. A vizuális differenciálás feladatokat jól megoldotta.

\section{Következtetések}

A másfél éves fejlesztőprogram hatására a gyermek kognitív architektúrája harmonikussá vált, javult az olvasási technikája és helyesírása. Két éve már nem igényel segítséget, jól teljesít az általános iskolában.

\section{Irodalom}

Affolter, F. (1972). Az észlelési funkciók zavartalan és patológiás fejlodésének szempontjai. Torda Á. (1992, szerk.). Szemelvények a tanulási zavarok körébol. Tankönyvkiadó, Budapest

Alevriadou, A. (2010). Spatial location of movement by children with intellectual disabilities: Automatically encoded or not?. Proocedia Social and Behavioral Sciences 2, 4707-4711. 
American Psychiatric Association (ApsyA) (2013). Diagnostic and Statistical Manual of Mental Disorders (V. ed.) (pp. 66-84) Washington DC: American Psychiatric Association

Demetriou, A., Shayer, M. és Efklides, A. (1994). Neo-Piagetian theories of cognitive development. Routledge, London

Djuric-Zdravkovic, A., Japundza-Milisavljevic, M. és Macesic-Petrovic, D. (2010). Attention in children with intellectual disabilities. Procedia Social and Behavioral Sciences 5, 1601-1606.

Engel-Yeger, B., Hardal-Nasser, R. és Gal, E. (2011). Sensory processing dysfuntions as expressed among children with different severities of intellectual developmental disabilities. Research in Developmental Disabilities 32, 1770-1775.

Falik, L. H. és Feuerstein, R. S. (2005). The current state and development of the learning propensity assessment device (LPAD). Erdélyi Pszichológiai Szemle, különszám, 17-54.

Kiss, A. és Zsoldos M. (2008). A képességrendszer változásai fejlesztésben részesülő tanulóknál. A Sindelar-program tapasztalatai. In Németi, J. (ed.). Tanulmányok a tanulásban akadályozottak pedagógiája és határtudományai köréböl. Sulinova, Educatio Társadalmi Szolgáltató Közhasznú Társaság, Budapest

Mesterházi, Zs. (1995). A tanulási képességről és a tanulási akadályozottságról. Gyógypedagógiai Szemle, XXIII./1, Magyar Gyógypedagógusok Egyesülete, Budapest.

Sarkady, K. és Zsoldos, M. (1992/93) Koncepcionális kérdések a tanulási zavar körül. Magyar Pszichológiai Szemle, 3-4, 259-270.

Sedlak, F. és Sindelar, B. (2000). "De jó, már én is tudom!"ELTE - BGGYTF, Bp.

Sindelar, B. (1994). Teilleistungsschwächen. Wien, Eigenverlag

Sindelar, B. (2010). Vizsgálóeljárás az iskolás gyermekek részképességeinek felismerésére a Tréningprogram használatához. Nyomdaipari és Kiadói Szolgáltató Kft, Budapest

Sindelar, B. (2010). Útmutató. Nyomdaipari és Kiadói Szolgáltató Kft, Budapest

Szabó B. (2006). Inkluzív nevelés. Ajánlások értelmileg akadályozott gyermekek kompetencia alapú fejlesztéséhez. - Óvodai nevelés. SuliNova Közoktatás-fejlesztési és Pedagógus-továbbképzési Kht., Budapest

Wastendorp, M., Houwen, S., Hartman, E. és Visscher, C. (2011). Are gross motor skills and sports participation related in children with intellectual disabilities? Research in Developmental Disabilities, 32, 1147-1153.

Zsoldos, M. (1999). A tanulási és magatartási zavarok kognitív terápiája- A Sindelarprogram. Gyógypedagógiai szemle. 27/2, 94-101. 